\title{
Viral infections and asthma: an inflammatory interface?
}

\author{
Brian G.G. Oliver ${ }^{1,2}$, Paul Robinson ${ }^{2,3,4}$, Mathew Peters ${ }^{5,6}$ and Judy Black ${ }^{2}$
}

\section{Affiliations:}

'School of Medical and Molecular Biosciences, University of Technology Sydney, Sydney, Australia.

${ }^{2}$ Woolcock Institute of Medical Research, Sydney Medical School, The University of Sydney, Sydney, Australia.

${ }^{3}$ Dept of Respiratory Medicine, The Children's Hospital at Westmead, Sydney, Australia.

${ }^{4}$ The Children's Hospital at Westmead Clinical School, The University of Sydney, Sydney, Australia.

${ }^{5}$ Australian School of Advanced Medicine, Macquarie University, Sydney, Australia.

${ }^{6}$ Dept of Thoracic Medicine, Concord General Hospital, Concord, Australia.

\section{Correspondence:}

Brian G.G. Oliver, School of Medical and Molecular Biosciences, University of Technology Sydney, Building 4, Level 6, City Campus, PO Box 123, Broadway, Sydney, NSW 2007, Australia.

E-mail: brian.oliverQuts.edu.au

ABSTRACT Asthma is a chronic inflammatory disease of the airways in which the majority of patients respond to treatment with corticosteroids and $\beta_{2}$-adrenoceptor agonists. Acute exacerbations of asthma substantially contribute to disease morbidity, mortality and healthcare costs, and are not restricted to patients who are not compliant with their treatment regimens. Given that respiratory viral infections are the principal cause of asthma exacerbations, this review article will explore the relationship between viral infections and asthma, and will put forward hypotheses as to why virus-induced exacerbations occur. Potential mechanisms that may explain why current therapeutics do not fully inhibit virus-induced exacerbations, for example, $\beta_{2}$-adrenergic desensitisation and corticosteroid insensitivity, are explored, as well as which aspects of virus-induced inflammation are likely to be attenuated by current therapy.

@ERSpublications

Why do virus-induced asthma exacerbations occur? Mechanisms and interventions http://ow.ly/zh126 


\section{Introduction}

Asthma is an intriguing disease that is perhaps best thought of as a series of overlapping aberrant biological processes that ultimately result in airway inflammation and characteristic airway physiology. While inflammation is a hallmark feature of asthma, asthmatic inflammation is not homogeneous. This is exemplified in studies that have measured granulocytes in induced sputum. In such studies, asthmatic pathology can be classified as eosinophilic, neutrophilic, mixed or paucigranulocytic (neither) [1]. Altered airway function is manifest in symptoms such as shortness of breath, cough and wheeze, and is characterised physiologically by airway hyperresponsiveness (AHR). AHR represents airway contraction in response to concentrations of agonists that are without effect in the nonasthmatic, together with reversible airflow limitation. Fortunately, even with the heterogeneity that exists in the various clinical and biological phenotypes of asthma, corticosteroids and $\beta_{2}$-adrenoceptor agonists are clinically useful therapies for the majority of patients. However, even though symptoms can be well controlled for long periods of time by corticosteroids and $\beta_{2}$-agonists, viral respiratory tract infections can cause symptom relapse or exacerbations. The reason(s) why viruses cause exacerbations of asthma is not known; simplistically, viral infection could contribute to asthma symptoms and/or change airway physiology. The purpose of this review is to put forward hypotheses as to why virus-induced exacerbations occur and to discuss potential mechanisms that may explain why current therapeutics do not fully inhibit virus-induced exacerbations.

\section{Asthma}

Asthma is a chronic lung disease in which corticosteroids are used to control airway inflammation and $\beta_{2}$-agonists provide bronchodilatation. These are the most effective current treatments for asthma, and when taken concomitantly, their efficacy is generally increased. In the absence of any exacerbant (i.e. a stimulant that causes symptom control to relapse), optimal treatment reduces asthma symptoms, peak expiratory flow variability and indices of inflammation. Exacerbations are characterised by worsening asthma symptoms and a fall in lung function, and contribute substantially to the cost and burden of asthma. For example, in New South Wales (a state of Australia with a population of around 7 million) there were 22942 emergency department visits for asthma, of which 42\% resulted in hospital admission in 2007 [2]. The annual cost per person for hospital admissions can reach around $€ 15000$. In addition to the direct medical costs, the costs of absenteeism from work/school are thought to account for $50 \%$ of the total cost of treating asthma. While the majority of asthma exacerbations occur in those who are not compliant with medication usage, it is important to note that viruses can cause even the well-controlled patient to exacerbate [3].

\section{Viruses and asthma}

There is overwhelming evidence demonstrating the association of asthma exacerbations with viral infections in the community. JOHNSTON et al. [4] were amongst the first to show the extent and ramifications of viral infections in asthmatic school children using PCR techniques in combination with other well-established viral detection methods. In this seminal study, 108 children aged between 9 and 11 years old were monitored by peak flow measurements, and viral sampling was obtained during symptomatic episodes. Viruses were isolated in $77 \%$ of episodes, of which picornaviruses were the predominant viruses identified (147 episodes, 50\%). Coronaviruses were the second most prevalent, being isolated in 38 (13\%) episodes; parainfluenza and influenza were isolated in 21 (7\%) episodes each; and respiratory syncytial virus (RSV) was isolated in $12(4 \%)$ episodes. Rhinovirus was found to be the predominant virus within the picornavirus group, as it was identified in 84 episodes, while relatively few had more than two different viruses detected (5\%) [4]. In comparison to children, a similar proportion (80\%) of adults has been shown to have a viral infection at the time of episodic asthma worsening [5]; however, others have found lower detection rates of virus in adults $[6,7]$. Several reasons may account for this discrepancy. The time taken for adults to present with symptoms could be longer in comparison to that in children, virus replication may be reduced and/or greater clearance may occur in adults.

While the association of viral infections and exacerbations of asthma is clearly defined, the role of viral infections in the aetiology of asthma itself is more controversial. Several studies have suggested a causal role, as outlined below. However, given the fact that both RSV and rhinovirus are particularly promiscuous in infants, infecting $80-90 \%$ of all children by the time they reach two years of age $[8,9]$, a simple cause-andeffect hypothesis does not hold. Two long-term follow-up studies have both demonstrated sequelae from severe RSV infection early in life (defined as requiring hospitalisation) at entry to adulthood: KorpPI et al. [10] demonstrated deficits in lung function following RSV in the first 2 years of life, while Sigurs et al. [11] have shown increased rates of asthma (not found in the studies of KoRPPI et al. [10]) in a cohort requiring hospitalisation in the first 6 months of life. Milder RSV infection up to the age of 3 years in the Tucson Birth Cohort was associated with increased risk of wheeze up to 11 years of age [12]. The association 
between RSV infection and the subsequent development of asthma appears to change with age. A recent meta-analysis found that the attributable risk of developing asthma following RSV infection was 13-22\% in children $\leqslant 5$ years, $11-27 \%$ in children aged $5-11$ years and was $32 \%$ in children aged $\geqslant 12$ years [13]. More recent data from the Childhood Origins of Asthma (COAST) cohort suggest a stronger association between rhinovirus and subsequent asthma risk. In this prospective study in a cohort of 259 children, rhinovirus infection was highly associated with the development of wheeze at 3 years and asthma at 6 years of age $(\mathrm{OR} \sim 10)[14,15]$. When virus-induced wheeze up to age 3 years was correlated to the presence of asthma at 6 years of age, the odds ratio reported for rhinovirus was almost four times that of RSV (OR 9.8 versus 2.6) and reached 10 for both viruses taken together. This suggests a more important aetiological role for rhinovirus than RSV and is echoed by other studies describing the impact of rhinovirus in this early childhood setting [13, 16, 17]. Many confounding factors influence the validity of such results. The frequency of asthma in the community is greater in children than in adults but asthma can develop later in life. Therefore, when studies are carried out examining the effects of viral infection in infancy upon the development of asthma at static time-points, it is plausible that the estimations of causality are inaccurate.

The timing and frequency of viral infections may also be important. Infancy represents a rapid period of growth for both the immune system and lung development. During this "susceptibility" period, viral infections may have their largest impact [18]. Infants experiencing viral seasons (e.g. RSV) during the first 6 months of life have a higher prevalence of asthma [19,20]. Animal studies have shown that early viral insults can affect the immune system with long lasting effects on immune and pulmonary function [21, 22]. The importance of the frequency of lower respiratory tract infection is suggested by data from the German Multicentre Allergy Study, which followed 1314 children from birth to 13 years of age [23]. Children who had more than one viral infection of the upper respiratory tract (defined by a runny nose) during the first year of life had a decreased likelihood of developing asthma at age 7 years, while in the same study, children who had two or more (evidence more powerful for four or more) lower respiratory tract infections during the first 3 years of life were at a greater risk of developing asthma at age 7 years [23].

The alternate explanation for such studies is that these early viral infections are simply the first marker of an underlying predisposition to asthma, due to abnormal lung function and/or genetic factors, rather than a key insult in the development of asthma [18]. Studies attempting to answer this question have produced conflicting results to date [24, 25], although a recent analysis of two large separate birth cohorts (COAST study and Copenhagen Prospective Study on Asthma in Childhood) identified a virus-specific association between genetic variation at the 17q21 locus, rhinovirus-induced wheezing illness and childhood asthma [26]. To date, there is no clear evidence that there is a true increased susceptibility to infection in these individuals. However, there are several other important factors that appear to modify subsequent asthma risk in these young children. The German Multicentre Allergy Study showed that it was the presence of early atopic sensitisation in the first few years of life that influenced subsequent asthma outcomes [27]. KUSEL et al. [28] demonstrated in a smaller cohort of almost 200 children, followed from birth to 5 years, that the presence of sensitisation early on (at or before the age of 2 years) appeared to magnify the risk associated with viral infection of subsequent asthma.

The current view is that development of asthma in childhood is multifactorial, reflecting both genetic predisposition and multiple environmental exposures occurring at critical time-points as the child develops. These include viral respiratory infections [29, 30], delayed immune system maturation [31] and allergic sensitisation [28]. The temporal relationship between these factors is unclear. The genetic composition of an individual may also bias such experiments. A maternal history of asthma increases the risk of severe lower respiratory tract infection during the first year of life, independent of the risk of developing asthma. Recent data have shown that better maternal asthma control during pregnancy is associated with a significant decrease in the number of episodes of bronchiolitis occurring during infancy [32]. Similarly, a maternal history of bronchiolitis increases the risk of childhood lower respiratory tract infections [33]. In children who wheeze post-bronchiolitis, there is increased occurrence of genetic polymorphisms in the interleukin (IL)-8 gene, both in comparison with nonwheezers and the general population [34]. Attempts to investigate the effect of associations between virus infection and the host immune system on subsequent asthma development or exacerbations in those with pre-existing asthma often focus on a single viral type, and may possibly overlook the role of multiple concurrent infections. Given that the frequency of two concomitant respiratory viral infections is around $20-30 \%[35,36]$, it could be this interaction between the different infections and the host immune system that primes and/or stimulates the lungs to develop asthma.

\section{The difference between poorly controlled asthma and asthma exacerbations}

The most commonly used definition of an asthma exacerbation requires not an event of a particular character but the management of it, whether that be hospitalisation, emergency room presentation or a course of oral corticosteroids (OCS). Such an exacerbation can be an extension of the pattern of disease in 
ongoing poor control or an independent event. It is clear that some patients have excellent current control of asthma with minimal or no symptoms, and yet have sudden and severe exacerbations. Viral infections have been implicated in such events. At the other extreme, some patients have unrecognised or ineffectively managed asthma, and have extreme variability in symptoms and lung function. In these cases, exacerbations may be recorded not necessarily for the deepest fluctuations in lung function or for specific patterns of asthma worsening, but for those occasions where medical advice was sought and treatment given.

One particularly challenging aspect of asthma exacerbations is the differentiation between inadequate treatment regimens leading to episodic symptomatic asthma and catastrophic failures in asthma control in response to various stimuli, i.e. an exacerbation.

It can be argued that when medication regimens are not titrated according to objective features of asthma, insufficient treatment is delivered. Insufficient treatment may provide some benefits to the asthmatic patient in terms of reduced symptoms; however, as inflammation and AHR are likely not to be fully controlled, this may allow exacerbations to occur. The difference between poorly controlled asthma and asthma exacerbations is further compounded by the diversity of symptom severity or physiological measurements that are used by researchers to describe an exacerbation, and the fact that patients are often not compliant with therapeutic regimens. However, in the general community, asthma treatment guidelines and action plans do provide optimal treatment for asthmatic patients, and in clinical trials, in which medication usage is monitored and adjusted according to symptoms, exacerbations still occur.

\section{Can current therapeutic regimens prevent virus-induced exacerbations?}

There is no doubt that the reductions observed in asthma morbidity and mortality observed over the last 20 years are the result of better therapeutic management; however, the real question is, are asthma therapeutics effective in virus-induced exacerbations? Large studies have shown that even low-dose inhaled corticosteroids (ICS) reduce exacerbations and the risk of death from asthma [37]. For example, in comparison to no treatment, $100 \mu \mathrm{g}$ budesonide twice daily resulted in a $60 \%$ reduced risk of having a severe exacerbation in the OPTIMA (Oxis and Pulmicort Turbuhaler in the Management of Asthma) trial [38]. The addition of a long-acting $\beta_{2}$-agonist (LABA) to ICS further reduces the frequency [39], severity and duration [40] of exacerbations. Studies such as these were not designed to identify the cause of the exacerbation; however, as viruses are thought to cause $\geqslant 50 \%$ of all exacerbations, it is reasonable to assume that some reduction in the incidence of virus-induced exacerbations would occur. None of these studies specifically identified whether improved asthma management does one or more of the following: 1) reduces the rate of respiratory viral illnesses; 2) reduces the rate at which respiratory viral infections trigger a sequence of inflammatory events that will result in an exacerbation; or 3) reduces the severity of symptoms or lung function such that the episode does not require exacerbation-defining medical intervention.

In a prospective, multicentre study of 413 asthmatics, WALTER et al. [41] aimed to determine factors that would predict loss of asthma control following a cold. In their study, there was no association between the use of ICS with or without $\beta_{2}$-agonists and loss of asthma control [41]. The severity or number of previous colds was also not associated with loss of asthma control, but the severity of the first 2 days of the current cold could be used to predict loss of asthma control. If we were to assume that all viruses are equal, i.e. have the same pathogenicity, it would be likely that other cofactors would precipitate the exacerbation; however, not all viruses are equal. As shown by WARK et al. [42], even serotypes of the same virus can have dramatically different innate immune responses in vitro. There is emerging evidence suggesting that the recently described group of rhinoviruses, rhinovirus $\mathrm{C}$, appears to cause more severe infections in vivo, at least in children $[43,44]$. This may not be the case for adults [45]. This suggests that the gene-environment hypothesis (where the role of any given gene is determined by the environment) can now be extended to include the gene-virus hypothesis, where the interaction of the specific virus and the host immune response will dictate whether an exacerbation occurs or not.

\section{Are corticosteroids effective or ineffective during virus-related infections?}

Corticosteroids are known to improve asthma symptoms and decrease exacerbations; however, virusinduced exacerbations can occur in ICS-treated asthma in patients who are well controlled [3]. Clearly, a component of specific virus-induced inflammation is not controlled by stable ICS therapy. Whether ICS have no effect on virus-induced asthma deterioration is much less clear. In patients using budesonide/ formoterol maintenance and either terbutaline, formoterol or formoterol/budesonide as a reliever, the exacerbation rate after the onset of reported "cold" symptoms was reduced by as-needed budesonide/ formoterol compared with as-needed formoterol reliever [46]. Even in that setting, there is potential confounding by an effect of the additional as-needed ICS on residual eosinophilic airway inflammation rather than viral mechanisms. 
In vitro, we and others have found that steroids inhibit rhinovirus [47-49] and RSV-induced cytokine release, supporting the notion that the use of steroids in vivo would suppress virus-induced inflammation. Interestingly, data from in vitro studies have suggested that the timing of administration of steroids has profound effects upon their ability to inhibit virus-induced cytokines. For example, in bronchial epithelial cells, rhinovirus-induced CXCL-10 was inhibited by budesonide when the drug was given at the start of the infection period [50], but not when applied $24 \mathrm{~h}$ prior to infection [51]. Quite how these in vitro results translate into clinical practice is uncertain. It is clear that patients with asthma who have poor adherence to medication regimens (for a review, see that by HoRne [52]) have worse asthma-related outcomes, but this is perhaps an extreme example of incorrect medication usage.

Recent in vitro studies have revealed a molecular mechanism of corticosteroid resistance in rhinovirusinfected cells [53]. Corticosteroid resistance is often misinterpreted as a complete lack of response to corticosteroids, rather than the correct meaning of reduced efficacy of the corticosteroids. So to achieve a desired level of inhibition in the context of corticosteroid resistance, it is necessary to increase the dose, bearing in mind that maximal effect might never be achieved. With traditional fixed-dose treatment regimens, inflammatory states that cause corticosteroid resistance are of particular concern, because if the dose of steroid remains constant, this may be insufficient to control inflammation. In theory, this could be overcome by increasing the dose of steroid as part of an asthma management plan, yet clinical evidence is lacking to support this approach in either children or adults [54]. An age-related effect may also exist and may reflect the underlying nature of the inflammation. In pre-schoolers with virus-induced wheeze exacerbations, no beneficial effect of routine OCS use has been shown, either parent-initiated [55] or physician-initiated once in the emergency department [56]. High-dose ICS (750 $\mu$ g fluticasone propionate twice daily) from the start of a viral illness has, however, been shown to reduce the subsequent need for OCS, but attractiveness of this approach was tempered by a detrimental effect on growth [57]. In older children, the beneficial effect of OCS in these settings $[58,59]$ may in part reflect a greater role for nonviral inflammatory aetiologies (e.g. eosinophilic due to allergic triggers). As-required use of combination inhalers containing a fast-onset, long-acting bronchodilator and steroid are now beginning to be used in clinical practice to treat adults with asthma, replacing the combination of short-acting bronchodilators and a separate corticosteroid-based inhaler; however, there is not enough evidence to suggest this is beneficial in comparison to traditional stepwise up-titration of steroid dose [60].

Corticosteroid resistance may occur in the context of viral infections and may contribute to the occurrence of an exacerbation. In most clinical trials measuring the efficacy of steroids with or without bronchodilators, the general observation is that asthma control is increased by the actions of steroids and is further increased by the addition of bronchodilators. However, even in these carefully carried out and monitored clinical trials, exacerbations still occur. The best example of this phenomenon is the study by ReDDEL et al. [3]. In that study, there is clear evidence that despite asthma being well controlled by steroids, exacerbations occur in the context of colds. If we now focus upon experimental infection models in human asthma, no reduction in rhinovirus-induced inflammation has been observed when using a fixed dose of inhaled steroid $[61,62]$. Furthermore, even oral prednisone has been shown to be ineffective in controlling rhinovirusinduced asthma symptoms [63], and moreover, to increase viral titres [64].

When the dose of ICS used in asthma is considered, there is no benefit from doubling ICS dose for treatment of exacerbations $[65,66]$ and this approach is now considered insufficient for the management of asthma [67]. A recent study by OвORNE et al. [68] extended this finding and evaluated the efficacy of quadrupling the usual dose of ICS at the first symptoms of a cold; however, this approach did not reduce exacerbations in comparison to placebo.

Taken together, these studies suggest that corticosteroids should provide some immunosuppression in the context of respiratory viral infections, but it is likely that they do not fully inhibit virus-induced inflammation or symptoms. They therefore fail to stop the occurrence of virus-induced exacerbations or reduce their severity below the threshold where medical attention is sought and treatment given.

\section{Do respiratory viral infections reduce $\beta_{2}$-agonist efficacy?}

REDDEL et al. [3] provided the first objective evidence for loss of $\beta_{2}$-agonist efficacy in asthmatics with a cold. In their study, peak expiratory flow was monitored in asthmatics both prior to and after treatment with the ICS budesonide. Prior to ICS treatment, peak expiratory flow had characteristically high diurnal variation and, following ICS treatment, good asthma control was reflected by increased peak expiratory flow and decreased variability. In the study volunteers, even though good asthma control had been achieved, 39 exacerbations associated with clinical colds occurred. In these, peak expiratory flow declined and recovered over 7-14 days. Importantly post- $\beta_{2}$-agonist and evening peak flow values were no higher than pre- $\beta_{2^{-}}$ agonist and morning values, implying impaired response to $\beta_{2}$-agonist. During these exacerbations, diurnal 
variability was not significantly different from that observed during good asthma control. This study provides evidence that viral exacerbations have different pathophysiological mechanisms in comparison to untreated or poorly controlled asthma. One of the proposed mechanisms by which virus infections limit the action of $\beta_{2}$-agonists is via the production of mucus [69]. While it is possible that increased mucus in the airway lumen following virus infection could impair $\beta_{2}$-agonist efficacy by reducing the amount of drug reaching the smooth muscle, $\beta_{2}$-agonists have clinical benefit in respiratory diseases with abnormal mucus production such as cystic fibrosis [70, 71] and COPD [72]. It is therefore likely that viral infection of the airway may affect the inherent ability of the airway smooth muscle to respond to $\beta_{2}$-agonists. A second proposed mechanism to explain the lack of response to $\beta_{2}$-agonist that occurs during viral infections is the development of tolerance. The development of tolerance to $\beta_{2}$-agonists can be experimentally demonstrated both in vivo [73] and in vitro [74]; however, in the aforementioned study by REDDEL et al. [3], $\beta_{2}$-agonist use was lower during viral exacerbations than during the initial period of poor asthma control and, as such, tolerance is unlikely to account for the changes. A third potential mechanism to explain the reduced efficacy of $\beta_{2}$-agonists during viral infections is the possibility that obstruction occurs as a direct result of inflammation. Inflammation is accompanied by increased microvascular leakage and tissue oedema. Oedema would act to thicken the airway wall, therefore decreasing lumen size. Increased vascular permeability occurs as asthma control deteriorates [75]; however, oedema is not related to changes in AHR during allergen challenges [76]. This finding is supported by studies in animals that have found that oedema causes only modest airway narrowing [77]. The exact contribution of oedema to airway obstruction during virus-induced exacerbations is not known, but it is perhaps not likely to be the primary cause of reduced airflow. In an attempt to understand the mechanisms responsible for the decreased $\beta_{2}$-agonist efficacy observed during viral infections, we have established an in vitro model [78] to test the hypothesis that virus infection impairs $\beta_{2}$-adrenoceptor activation. Since it is now accepted that rhinovirus reaches, infects and replicates in lower airway epithelium [79], our model uses a co-culture system in which epithelial cells are infected with rhinovirus and conditioned medium is used to treat airway smooth muscle cells prior to assessing $\beta_{2}$-adrenoceptor function. We chose to use rhinovirus as the model virus, as it is responsible for at least half of all virus-induced asthma exacerbations. In our study, we observed that $\beta_{2}$-agonist-induced cAMP was reduced in airway smooth muscle cells that had been treated with conditioned medium from virally infected epithelial cells. We propose that this response is specific to replicating rhinovirus, as no reduction in $\beta_{2}$-agonist-induced cAMP occurred in response to conditioned medium from epithelial cells treated with ultraviolet (UV) radiation-inactivated virus, polyinosic:polycytidylic acid (a surrogate for other viruses) or the bacterial endotoxin lipopolysaccharide. Using flow cytometry, we were able to assess membrane and total $\beta_{2}$-adrenoceptor levels. Following exposure to rhinovirus conditioned medium, airway smooth muscle cell surface, but not total, $\beta_{2}$-adrenoceptor number was reduced, suggesting that desensitisation of the $\beta_{2}$-adrenoceptor had occurred. In recent studies, we have identified the mechanism by which desensitisation occurs [80]. Rhinovirus replication in epithelial cells is not perfect, and in addition to progeny, viral particles and unpackaged viral RNA are also released from infected cells [81, 82]. We took the cell culture supernatant from rhinovirus-infected primary bronchial epithelial cells and were able to detect viral RNA. We purified the viral RNA and, as a control, used human mRNA, and used both to stimulate

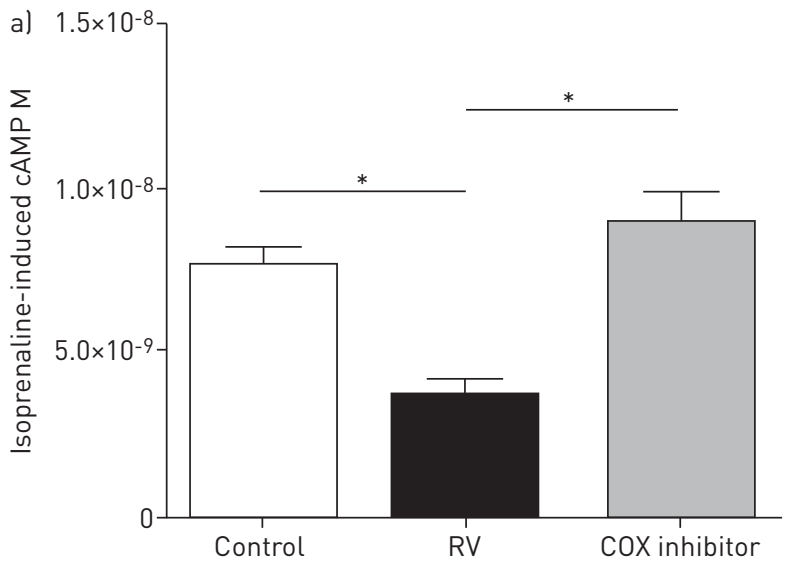

b)

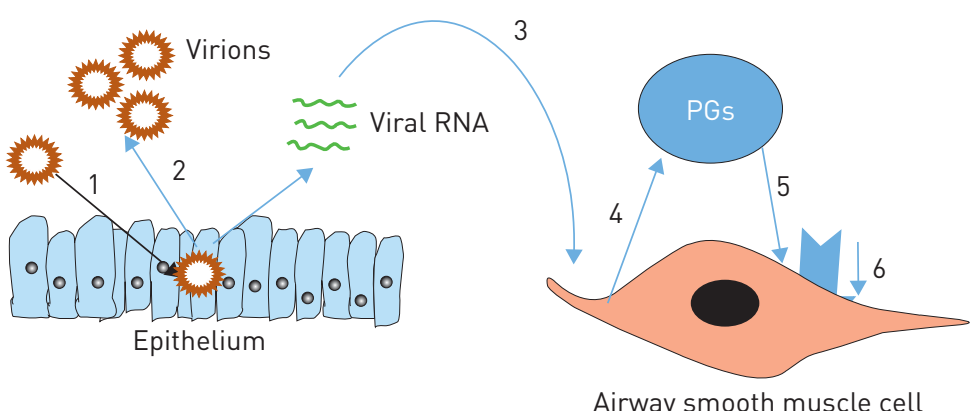

FIGURE 1 Rhinovirus (RV)-induced $\beta_{2}$-adrenoceptor desensitisation. a) Inhibition of cyclo-oxygenase (COX) restores $\beta_{2}$-adrenoceptor function in airway smooth muscle cells treated with conditioned medium from RV-infected epithelial cells. Reproduced from [80]. b) A cartoon of the proposed mechanism of $\beta_{2}$-adrenoceptor desensitisation. 1) RV infects epithelial cells and replicates, 2) releasing progeny virions and viral RNA. 3) The viral RNA is detected by airway smooth muscle cells and stimulates 4) the production of prostaglandins (PGs). 5) These PGs act in an autocrine manner to 6) cause $\beta_{2}$-adrenoceptor desensitisation. 
airway smooth muscle cells. We found that only viral RNA stimulated prostaglandin release from airway smooth muscle cells. As depicted in figure 1, the prostaglandins acted through an autocrine mechanism to cause $\beta_{2}$-adrenoceptor desensitisation. Reduced total cellular expression of the $\beta_{2}$-adrenoceptor has also been shown to occur in vitro when airway smooth muscle cells are directly infected with RSV [83]. This study is interesting but caution has to be observed when examining the direct effect of viral infection upon a cell. Viruses subvert the host machinery in order to manufacture progeny viruses and, in turn, the cell attempts to apoptose to limit viral spread. As such, it would be important to show specific downregulation of a given receptor, rather than a global downregulation prior to apoptosis.

\section{Leukotriene receptor antagonists}

For many years leukotrienes have been suggested to be important in the pathology of virus-induced exacerbations; however, there is a marked paucity of in vivo and in vitro studies exploring this hypothesis. Respiratory tract viral infection upregulates 5-lipoxygenase in the bronchial mucosa [84], an enzyme needed in the cellular production of leukotrienes. Elevated leukotriene $\mathrm{C}_{4}$ is found in nasal lavage fluid after experimental infection with either rhinovirus, RSV or influenza virus A [85], thus providing some evidence for the potential involvement of leukotrienes in virus-induced exacerbations. Targeted therapy such as the leukotriene receptor antagonist montelukast, when used as monotherapy, has been shown to be only modestly effective during respiratory tract infection-induced wheeze [86], but it is important to note that, in the same study, montelukast had similar efficacy to ICS. Furthermore, in a randomised, double-blinded, placebo-controlled trial, the addition of montelukast to usual therapy resulted in a $53 \%$ reduction in days with worse asthma symptoms compared with placebo and a $78 \%$ reduction in unscheduled physician visits for asthma [87]. However, the exact nature of the involvement of leukotrienes in the pathogenesis of rhinovirus and other respiratory viral infections is controversial. For example, in an experimental rhinovirus infection model, montelukast had no effect upon rhinovirus-induced colds or asthma symptoms [88]. Montelukast has also been found not to affect respiratory symptoms after RSV bronchiolitis [89, 90], or the incidence of upper respiratory tract infections [91].

\section{Clues from virus-induced inflammation}

The immune response to naturally acquired respiratory viral infections is complicated due to the heterogeneity of responses observed between different virus genotypes and serotypes, the effects of concurrent environmental stimuli, and pharmacotherapy. One approach to overcome such confounders is to experimentally infect volunteers. Experimental rhinovirus infections can induce asthma exacerbations [92], and reduce peak expiratory flow in both asthmatic [93] and nonasthmatic [94] subjects.

Airway eosinophilia is a characteristic of asthma, and many reports exist showing the relationship between eosinophil activation and recruitment in rhinovirus-infected asthmatic volunteers. Given the correlation between increased AHR and eosinophil recruitment and activation, for example, as assessed by eosinophil cationic protein (ECP) levels [95], it is tempting to speculate causality. However, an increase in eosinophil numbers $[95,96]$ has not been found in any human experimental rhinovirus infection study. Mouse models of rhinovirus exacerbations against a background of ovalbumin-induced allergic airways disease exhibit increased AHR accompanied by increased eosinophil numbers [97]. Interestingly, in such models, the development of AHR is inhibited by the administration of anti-eotaxin-1 [98]. However, in the context of the murine model of house dust mite-induced allergic airway disease, rhinovirus infection does not induce eosinophilia [99]. The contrasting results from the two mouse models perhaps tell us more about the utility of the models [100] than the putative role of the eosinophil. In animal models of RSV and Sendai (parainfluenza) infection, eosinophils have been found to be important in viral clearance [101, 102], raising the possibility that eosinophilic inflammation is beneficial under certain circumstances.

The role of the eosinophil in asthma is complex. For example, in people with severe asthma treated with corticosteroids, the presence of eosinophilia is associated with more frequent exacerbations [103]. In such populations, treatment with mepolizumab (anti-IL-5) reduces both the number of eosinophils and exacerbations [104]. In steroid-responsive asthma, airway eosinophilia is reduced by ICS, and it is this fact that has enabled eosinophilia to be used as a biomarker to assess optimal ICS treatment [105].

It is our view that virus-induced eosinophilia is unlikely to account for the failure of asthmatic treatment regimens during virus-induced exacerbations. In contrast, the role of the neutrophil in both the aetiology and pathogenesis of asthma is unclear. Rhinovirus infection increases circulating and bronchial lavage neutrophils in asthmatic volunteers [106], and both neutrophil number and the neutrophil chemokine IL-8 negatively correlate with airway function in experimentally infected volunteers [107, 108]. The relationship between corticosteroid use/efficacy and neutrophilic inflammation is potentially confounded as corticosteroids reduce airway eosinophilia (and therefore increase the proportion of neutrophils) and 
inhibit neutrophil apoptosis. However, in a study of 205 patients, multivariate linear regression has shown no association of airway neutrophilia with corticosteroid use [109], and airway neutrophilia occurs in asthmatic patients who are corticosteroid naïve [110]. In the absence of acute infection, the presence of airway neutrophilia is associated with steroid-insensitive asthma [111]; therefore, virus-induced neutrophilia could represent the steroid-insensitive component of virus-induced exacerbations. As such, virus-induced neutrophilia deserves further consideration.

The exact role of neutrophils during virus infections of the lung and the ensuing asthma exacerbation is not known, largely because existing therapies for asthma do not directly target neutrophils. Phosphodiesterase (PDE)-4 inhibitors, as used in COPD, and a newer experimental class of therapy CXCR2 (CXCL8 receptor) antagonists offer some insights. PDE-4 inhibitors are a relatively new class of anti-inflammatory medication and their main mechanism of action is to suppress lung neutrophilia in vivo (for a review, see that by TENOR et al. [111]). In COPD, where $50 \%$ of exacerbations are caused by rhinovirus, PDE- 4 inhibitors reduced exacerbation frequency [112], suggesting neutrophilia is an important component of exacerbations. PDE-4 inhibitors were developed as a refinement to theophylline, a pan-PDE inhibitor, and like theophylline have anti-inflammatory properties. In contrast to theophylline, PDE-4 inhibitors such as roflumilast do not have direct bronchodilator activity [113], perhaps because direct bronchodilation is mediated through other PDEs such as PDE-3 [114]; however, the role of other PDEs in direct bronchodilation needs to be verified. We and others have shown that in vitro PDE-4 is the main PDE that degrades $\beta_{2}$-agonist-induced cAMP and, furthermore, we found the activity of PDE-4 to be increased in airway smooth muscle from people with asthma [115]. Whether increased PDE-4 in asthma equates to an increased susceptibility to $\beta_{2}$-adrenoceptor desensitisation remains to be determined. Preclinical models have found that bronchodilation induced by low-dose salbutamol is enhanced in the presence of PDE-4 inhibitors [116], raising the possibility that the reduction in exacerbation frequency observed in patients with COPD treated with roflumilast may in part be mediated by increased or sustained efficacy of $\beta_{2}$-agonists. CXCR2 antagonists are still in development, but a recent report has shown that one of them, SCH527123, is safe and, importantly, reduces exacerbations of asthma [117]. It is likely that these therapies work via suppression of the accumulation of neutrophils, presumably showing that the existing lung neutrophils are sufficient to combat the infection.

We [118] and others have shown that rhinovirus infection induces lung neutrophilia in murine models, but there are no studies which specifically examine the role of neutrophils in the context of an asthma exacerbation. NAGARKAR et al. [119] used a series of knockout mice and elegantly demonstrated that neutrophil-derived tumour necrosis factor $\alpha$ is critical for the development of AHR. They did not investigate which cells were responsible for neutrophil chemokine production, or if inhibition of neutrophil influx affected either the number of infectious virions or the clearance of rhinovirus.

Conventionally, exhaled nitric oxide is thought to reflect airway eosinophilia and is advocated as a biomarker to assess asthma control [120]. However, new evidence regarding the role of nitric oxide in the airways is emerging, and it is too simplistic to consider it a simple marker of inflammation. Exhaled nitric oxide is increased in people without asthma with naturally acquired upper respiratory tract infections [121] and is also elevated following experimental rhinovirus infection [122]. In vitro, nitric oxide inhibits rhinovirus replication and cytokine production [121], and the replication of influenza virus [123] and RSV [124], suggesting that it is likely to be important in virus-induced exacerbations. Importantly, in asthmatic volunteers who were experimentally infected with rhinovirus, the production of nitric oxide was negatively correlated with AHR to histamine [125], i.e. the production of nitric oxide was protective. Nitric oxide may represent a paradox in the context of viral infections and treatment with ICS. ICS are well known to inhibit exhaled nitric oxide; however, if nitric oxide limits virus replication and, therefore, presumably virusinduced inflammation, reduced nitric oxide by ICS would be detrimental. Further research is needed to elucidate the role of virus-induced nitric oxide in vivo.

\section{The host response to virus infection}

The host response to virus infection is complex, and dependent upon a number of variables such as the type and amount of virus, the immunocompetence of the host, and underlying disease pathology. Given this complexity, and given the importance of rhinovirus infection as a precipitant of asthma exacerbations, the following section discussing the host's response to viral infection is mainly focused upon the response to rhinovirus.

Rhinoviruses are relatively simple viruses. They have a single strand of positive-sense RNA that is packaged into an icosahedral capsid formed by three different viral proteins, while a fourth viral protein is found on the interior of the capsid and is in contact with the viral RNA [126]. They are classified according to molecular traits, being defined as species A, B or C. Species A mainly consists of viruses that infect cells via 
the low-density lipoprotein receptor family and species B of those that infect via intercellular adhesion molecule-1, while the receptor for species $\mathrm{C}$ is unknown.

The initial innate immune response to rhinovirus infection is considered to occur once the virus RNA has been delivered into the cytoplasm, as part of the infection process, and is recognised by pattern recognition receptors. However, several studies using UV-irradiated virus, which is incapable of replication, have suggested that binding to the receptor alone elicits similar responses to replication-competent (live) rhinovirus [127-131]. Interestingly, UV-irradiated rhinovirus has been found to be inert in a number of similar studies [132-135]. There are several potential explanations for the observed differences and the most likely, in our opinion, relates to differences in the amount of UV irradiation. When UV irradiation is insufficient, virus replication can occur, and when too much UV irradiation is used, the viral capsid is either partially or totally destroyed, making any interaction with cellular receptors very unlikely.

Rhinovirus is a single-stranded RNA virus, but during replication, a double-stranded RNA intermediate is formed, which is detected by different intracellular receptor families. Single-stranded viral RNA is recognised by both Toll-like receptor (TLR)-7 and -8, while double-stranded RNA is detected by TLR-3 and the RNA helicases RIG-I (retinoic acid-inducible gene) and MDA5 (melanoma differentiation-associated gene 5). While opposing conclusions regarding the importance of the two recognition systems have been found in different studies, it is likely that both receptor systems are important in eliciting the host's response to rhinovirus infection $[136,137]$.

Regardless of the exact cellular process used to detect a virus, the net result of detection is activation of the innate antiviral immune response, characterised by the robust induction of a plethora of pro-inflammatory cytokines, chemokines and antiviral mediators. This increased inflammation forms the basis of the prevailing hypothesis as to why viral infections cause asthma exacerbations. However, the million-dollar question is, why does this increase in inflammation cause some people with asthma to experience an exacerbation and others not to? One theory that has been put forward is that exacerbations occur in those with dysfunctional innate immunity.

No discussion of virus-induced inflammation would be complete without reference to the potential deficits in innate immunity in asthma. In 2005, the first of a series of studies from the UK demonstrating impaired rhinovirus-induced type I interferons in asthmatic epithelial cells in vitro was published [135]. This was followed by a similar study showing deficient rhinovirus-induced type III interferons [138]. As depicted in figure 2, the importance of these findings lies in the fact the type I and III interferons induce apoptosis and, therefore, limit virus replication. These reports sparked a flurry of research in the area, often with mixed results. LoPEZ-SouzA et al. [139] used a more complex in vitro model with differentiated epithelial cells. In their study, no differences in the production of rhinovirus-induced type I interferon was found. There is no obvious explanation for the discrepancy, and it is likely that differentiated epithelial cells produce different amounts of cytokines in comparison to undifferentiated cells, making the differences in the outcomes of the two studies difficult to interpret. However, other researchers have also found no differences in type I and III interferons between asthma and nonasthma in response to rhinovirus infection, both in vitro [140] and in vivo [141]. Similarly, no difference in interferon production has been observed in response to infection with either RSV or human metapneumovirus [142]. Interestingly, the group that initially reported impaired interferon production in response to rhinovirus infection in asthmatic epithelial cells has recently reported no differences in interferon production [143]. In their discussion of the potential reasons for the discrepant results, differences in underlying disease severity and/or degree of airway inflammation are suggested as

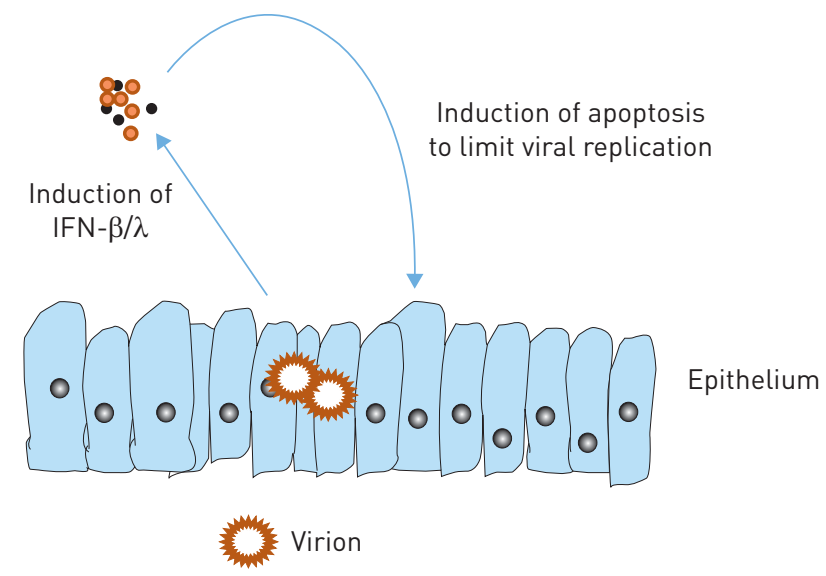

FIGURE 2 A cartoon illustrating the role of interferons (IFNs) in limiting virus infection. 
potential confounders. The weight of evidence suggests that deficient interferon production from asthmatic bronchial cells, as a general concept, is unlikely to occur; however, it remains to be seen if it is a feature of specific asthma phenotypes.

Irrespective of whether asthmatic cells release fewer type I or III interferons or not, the important question is, do ICS affect the production of type I or III interferons? In vitro, in our laboratory, we have found that the corticosteroids dexamethasone and fluticasone do not affect rhinovirus replication in primary lung cells [48], and there is good evidence to suggest that corticosteroids do not affect virus-induced type I interferons [135].

\section{The role of secondary or co-infection in virus-induced exacerbations}

Other pathogens have co-evolved with viruses and are able to use the window of opportunity created by viral infection and superinfect the host [144]. For example, it is well known that the rate of bacterial infection increases during episodic viral pandemics [145]. One mechanism by which superinfection occurs is by increased binding and retention of bacteria to the respiratory epithelium [146-149]. Furthermore, we have also shown that the innate immune response to bacteria is markedly impaired in virally infected alveolar macrophages [150]. In comparison to other diseases and pathogens, the role of bacterial infections in asthma exacerbations is controversial. However, asthmatics have increased susceptibility to invasive bacterial infection [151], and atypical bacterial infection has been reported to be reactivated in virusinduced asthma exacerbations [152] and related to exacerbation frequency [153]. There is also evidence that macrolide antibiotics, when used prophylactically $[154,155]$, or after the occurrence of an acute exacerbation [156] are effective treatments for asthma. If bacteria are co-conspirators in virus-induced exacerbations, it is highly likely that the exacerbation would not respond to ICS and $\beta_{2}$-agonists, as these drugs would not inhibit bacterial growth. Further research is needed in this area to fully describe the role of bacteria in virus-induced exacerbations.

\section{A role for allergens in rhinovirus-induced exacerbations of asthma}

While there is little doubt that both exposure to allergens and viral infections can induce asthma exacerbations, there is surprisingly little information regarding their interaction. It has proven to be very

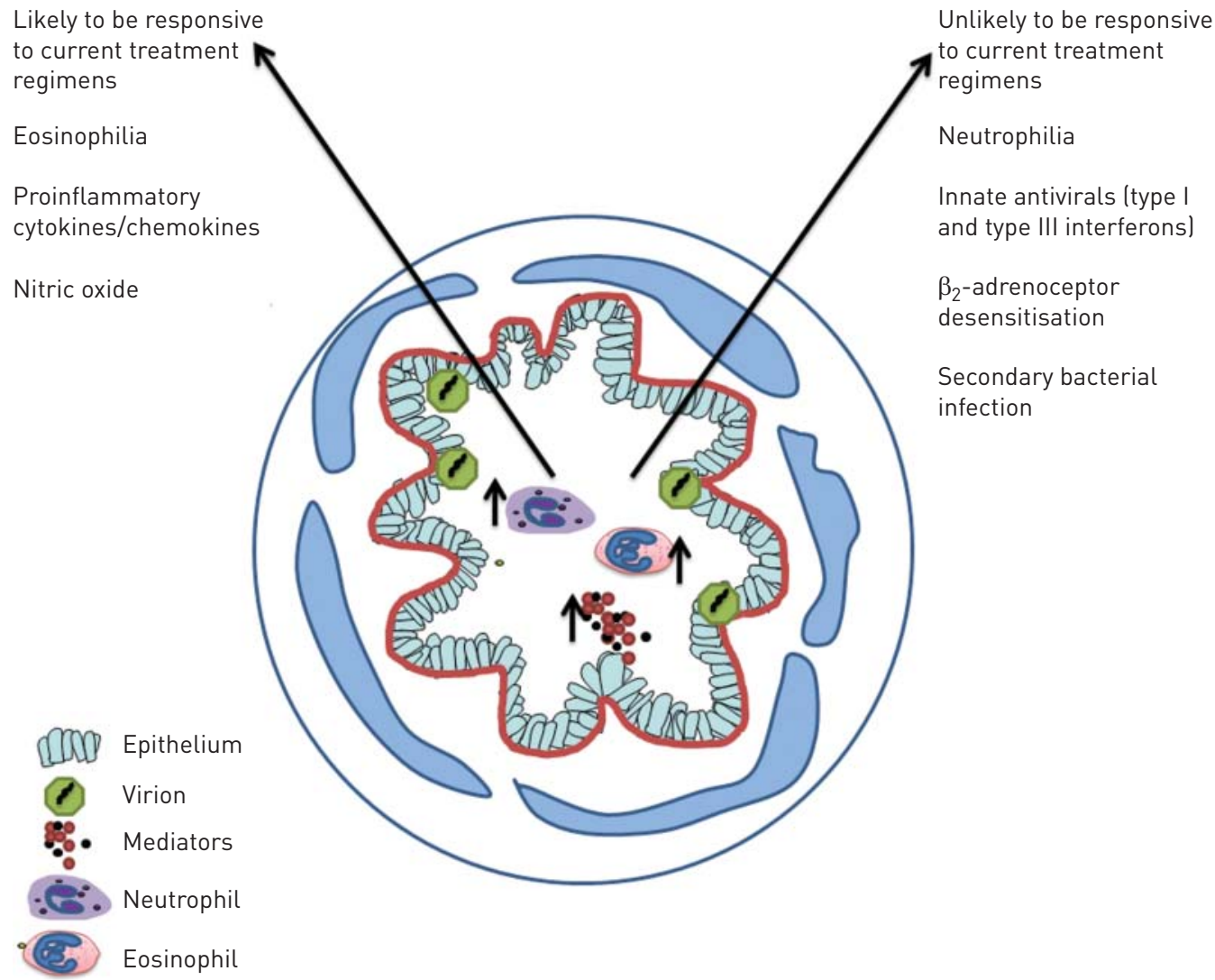

FIGURE 3 A cartoon depicting the consequences of viral infection and an indication as to whether these are likely to respond to current therapy. 
difficult to document personal allergen exposure leading to an exacerbation of asthma except in rare events such as thunderstorms $[157,158]$, and perhaps this is the reason why very few reports document the interaction between naturally acquired viral infections and allergen exposure in asthma exacerbations. GREEN et al. [159] provided evidence for synergism between virus infections and allergen exposure. In their case controlled study, the risk of being admitted to hospital was considerably increased by exposure to high levels of antigen and concurrent viral infection. This finding is supported by other studies that have measured the amount of IgE, and often specific IgE, to establish if any relationships exist between IgE levels and the likelihood of a virus-induced exacerbation. The first of this series of studies found the odds ratio for virusinduced wheeze in children over 2 years of age attending the emergency department was 4.4 if rhinovirus was detected. The concomitant presence of specific IgE increased the odds ratio to 17, which was higher if nasal eosinophilia or elevated nasal ECP was present (odds ratios of 21 and 25, respectively) [160]. This relationship may be specific to rhinovirus and not other viruses [161] and, furthermore, other studies indicate that rhinovirus C may be an important precipitant of exacerbations under such circumstances [162]. Systematic reviews have shown anti-IgE (omalizumab) to reduce exacerbations in children and adults with asthma [163], and in an elegant study by Busse et al. [164], omalizumab was shown to reduce exacerbations in spring and autumn, further providing evidence for the interaction between IgE and virus-induced asthma exacerbations. Such studies provided the basis for experimental studies in humans. The sequence of events is likely to affect the experimental outcomes; however, regardless of the sequence of exposure to allergen and viral infection, both stimuli have been shown to affect the subsequent response to the other. Experimental rhinovirus infection increases eosinophil recruitment into the lower airways and the occurrence of a late-phase response to allergen $[165,166]$. Antigen exposure followed by experimental rhinoviral infection 1 month later also induced a late-phase asthmatic response [167]. While changes can be observed in lung function parameters, in contrast, modulation of the immune response in terms of cytokine and chemokine induction is not altered by antigen exposure prior to rhinovirus infection. This is based on the fact that nasal IL-6 and IL-8 levels were not altered by antigen or placebo exposure prior to rhinovirus infection [168]. Similarly, lower airway IL-8 production was not further increased by prior repetitive exposure to low-dose house dust mite allergen [93].

\section{How could we stop virus-induced exacerbations?}

As described above and shown in figure 3, virus-induced asthma exacerbations are likely to involve multiple mechanisms and, as such, a single treatment modality is unlikely to be effective in all people with asthma. In order to completely stop virus-induced exacerbations from occurring, good asthma management would have to be implemented prior to a second prophylactic treatment strategy. Due to the cost and potential side effects of prophylactic treatment, it would be necessary to identify those who are at risk of a virusinduced exacerbation on a background of good asthma control, perhaps by close monitoring of their asthma or through the use of biomarkers. One such potential biomarker is interferon- $\gamma$-induced protein 10 (IP-10). WARK et al. [169] have shown that virus-induced exacerbations are associated with approximately four-fold higher serum IP-10 in comparison with nonviral exacerbations. An alternative strategy would be to predict when virus-induced exacerbations are likely to occur, for example, at times of the year when children return to school, so prophylactic treatment could be implemented seasonally. Of course, the ideal approach would be to eradicate respiratory viruses; however, realistically, this approach is not feasible. It is possible to immunise against both RSV [170] and influenza [171], but these are likely to provide "immunity" against only certain serotypes of virus and will not actually stop infection from occurring. While it is not possible to vaccinate against rhinovirus, this approach is being currently evaluated [172]. Antirhinovirals are being developed $[173,174]$, and antivirals are available for both RSV and influenza. The efficacy of such antiviral strategies in terms of preventing asthma exacerbations is not known. A recent advance in the pursuit of antivirals was the development of inhaled interferon- $\beta$. A phase II clinical trial has recently been completed [175] in which patients with asthma were randomised to inhaled interferon or placebo for 14 days within $24 \mathrm{~h}$ of cold symptoms. The primary study outcome was an improvement in the Asthma Control Questionnaire (ACQ)-6. When all volunteers were included in the analysis, inhaled interferon- $\beta$ did not improve ACQ-6; however, subgroup analysis revealed improvements in ACQ-6 in patients with more severe disease. The authors of the study propose the lack of effect in the patients with milder forms of asthma is due to relatively mild cold-associated asthma symptoms (statistically insignificant changes in ACQ-6). Interestingly, in all patients allocated to interferon- $\beta$, significant improvements in some secondary end-points (enhanced morning peak flow recovery, reduced need for additional medication and increased innate immunity biomarkers) occurs, whilst other secondary endpoints were either not changed (e.g. virus load) or reported (e.g. forced expiratory volume in $1 \mathrm{~s}$ ) in the study.

\section{Perspective}

In this century, our understanding of the relationship between virus infections and development of asthma has greatly expanded but is incomplete. This must be greatly expanded by studies in volunteers using 
bronchoscopic biopsies and biomarkers [107]. Future studies should evaluate the role of different viruses and virus serotypes of the same virus, and how effects are modulated by pre-existing asthma phenotype. Understanding basic mechanisms is necessary so that, armed with this knowledge, we can be aware of which aspects of infection are sensitive and resistant to current treatments. From that position, we can evaluate the effect of novel strategies and pharmacotherapies on virus-induced asthma exacerbations.

\section{References}

1 Simpson JL, Scott R, Boyle MJ, et al. Inflammatory subtypes in asthma: assessment and identification using induced sputum. Respirology 2006; 11: 54-61.

2 Australian Centre for Asthma Monitoring. Asthma in Australia. AIHW Asthma Series no. 3. Cat. no. ACM 14. Canberra, AIHW, 2008.

3 Reddel H, Ware S, Marks G, et al. Differences between asthma exacerbations and poor asthma control. Lancet 1999; 353: 364-369.

4 Johnston NW, Johnston SL, Duncan JM, et al. The September epidemic of asthma exacerbations in children: a search for etiology. J Allergy Clin Immunol 2005; 115: 132-138.

5 Nicholson KG, Kent J, Ireland DC. Respiratory viruses and exacerbations of asthma in adults. BMJ 1993; 307: $982-986$.

6 Teichtahl H, Buckmaster N, Pertnikovs E. The incidence of respiratory tract infection in adults requiring hospitalization for asthma. Chest 1997; 112: 591-596.

7 Atmar RL, Guy E, Guntupalli KK, et al. Respiratory tract viral infections in inner-city asthmatic adults. Arch Intern Med 1998; 158: 2453-2459.

8 Blomqvist S, Roivainen M, Puhakka T, et al. Virological and serological analysis of rhinovirus infections during the first two years of life in a cohort of children. J Med Virol 2002; 66: 263-268.

9 Kneyber MCJ, Steyerberg EW, de GR, et al. Long-term effects of respiratory syncytial virus (RSV) bronchiolitis in infants and young children: a quantitative review. Acta Paediatrica 2000; 89: 654-660.

10 Korppi M, Piippo-Savolainen E, Korhonen K, et al. Respiratory morbidity 20 years after RSV infection in infancy. Pediatr Pulmonol 2004; 38: 155-160.

11 Sigurs N, Aljassim F, Kjellman B, et al. Asthma and allergy patterns over 18 years after severe RSV bronchiolitis in the first year of life. Thorax 2010; 65: 1045-1052.

12 Stein RT, Sherrill D, Morgan WJ, et al. Respiratory syncytial virus in early life and risk of wheeze and allergy by age 13 years. Lancet 1999; 354: 541-545.

13 Szabo SM, Levy AR, Gooch KL, et al. Elevated risk of asthma after hospitalization for respiratory syncytial virus infection in infancy. Paediatr Respir Rev 2013; 13: Suppl. 2, S9-S15.

14 Jackson DJ, Gangnon RE, Evans MD, et al. Wheezing rhinovirus illnesses in early life predict asthma development in high-risk children. Am J Respir Crit Care Med 2008; 178: 667-672.

15 Lemanske RF Jr, Jackson DJ, Gangnon RE, et al. Rhinovirus illnesses during infancy predict subsequent childhood wheezing. J Allergy Clin Immunol 2005; 116: 571-577.

16 Takeyama A, Hashimoto K, Sato M, et al. Clinical and epidemiologic factors related to subsequent wheezing after virus-induced lower respiratory tract infections in hospitalized pediatric patients younger than 3 years. Eur J Pediatr 2014; 173: 959-966.

17 O'Callaghan-Gordo C, Bassat Q, Diez-Padrisa N, et al. Lower respiratory tract infections associated with rhinovirus during infancy and increased risk of wheezing during childhood. A cohort study. PLoS One 2013; 8: e69370.

18 Singh AM, Moore PE, Gern JE, et al. Bronchiolitis to asthma: a review and call for studies of gene-virus interactions in asthma causation. Am J Respir Crit Care Med 2007; 175: 108-119.

19 Aberg N. Birth season variation in asthma and allergic rhinitis. Clin Exp Allergy 1989; 19: 643-648.

20 Nielsen HE, Siersma V, Andersen S, et al. Respiratory syncytial virus infection - risk factors for hospital admission: a case-control study. Acta Paediatr 2003; 92: 1314-1321.

21 Culley FJ, Pollott J, Openshaw PJ. Age at first viral infection determines the pattern of T cell-mediated disease during reinfection in adulthood. J Exp Med 2002; 196: 1381-1386.

22 Sorkness R, Lemanske RF Jr, Castleman WL. Persistent airway hyperresponsiveness after neonatal viral bronchiolitis in rats. J Appl Physiol 1991; 70: 375-383.

23 Illi S, von ME, Lau S, et al. Early childhood infectious diseases and the development of asthma up to school age: a birth cohort study. BMJ 2001; 322: 390-395.

24 Thomsen SF, van der Sluis S, Stensballe LG, et al. Exploring the association between severe respiratory syncytial virus infection and asthma: a registry-based twin study. Am J Respir Crit Care Med 2009; 179: 1091-1097.

25 Wu P, Dupont WD, Griffin MR, et al. Evidence of a causal role of winter virus infection during infancy in early childhood asthma. Am J Respir Crit Care Med 2008; 178: 1123-1129.

26 Caliskan M, Bochkov YA, Kreiner-Moller E, et al. Rhinovirus wheezing illness and genetic risk of childhood-onset asthma. N Engl J Med 2013; 368: 1398-1407.

27 Illi S, von Mutius E, Lau S, et al. Perennial allergen sensitisation early in life and chronic asthma in children: a birth cohort study. Lancet 2006; 368: 763-770.

28 Kusel MM, de Klerk NH, Kebadze T, et al. Early-life respiratory viral infections, atopic sensitization, and risk of subsequent development of persistent asthma. J Allergy Clin Immunol 2007; 119: 1105-1110.

29 Sly PD, Kusel M, Holt PG. Do early-life viral infections cause asthma? J Allergy Clin Immunol 2010; 125: 1202-1205.

30 Jackson DJ, Johnston SL. The role of viruses in acute exacerbations of asthma. J Allergy Clin Immunol 2010; 125: $1178-1187$.

31 Macaubas C, de Klerk NH, Holt BJ, et al. Association between antenatal cytokine production and the development of atopy and asthma at age 6 years. Lancet 2003; 362: 1192-1197.

32 Mattes J, Murphy VE, Powell H, et al. Prenatal origins of bronchiolitis: protective effect of optimised asthma management during pregnancy. Thorax 2014; 69: 383-384.

33 Goetghebuer T, Kwiatkowski D, Thomson A, et al. Familial susceptibility to severe respiratory infection in early life. Pediatr Pulmonol 2004; 38: 321-328. 
34 Goetghebuer T, Isles K, Moore C, et al. Genetic predisposition to wheeze following respiratory syncytial virus bronchiolitis. Clin Exp Allergy 2004; 34: 801-803.

35 Heymann PW, Carper HT, Murphy DD, et al. Viral infections in relation to age, atopy, and season of admission among children hospitalized for wheezing. J Allergy Clin Immunol 2004; 114: 239-247.

36 Jartti T, Lehtinen P, Vuorinen T, et al. Respiratory picornaviruses and respiratory syncytial virus as causative agents of acute expiratory wheezing in children. Emerg Infect Dis 2004; 10: 1095-1101.

37 Suissa S, Ernst P, Benayoun S, et al. Low-dose inhaled corticosteroids and the prevention of death from asthma. N Engl J Med 2000; 343: 332-336.

38 O’Byrne PM, Barnes PJ, Rodriguez-Roisin R, et al. Low dose inhaled budesonide and formoterol in mild persistent asthma: the OPTIMA randomized trial. Am J Respir Crit Care Med 2001; 164: 1392-1397.

39 Pauwels RA, Lofdahl CG, Postma DS, et al. Effect of inhaled formoterol and budesonide on exacerbations of asthma. Formoterol and Corticosteroids Establishing Therapy (FACET) International Study Group. N Engl J Med 1997; 337: 1405-1411.

40 Matz J, Emmett A, Rickard K, et al. Addition of salmeterol to low-dose fluticasone versus higher-dose fluticasone: an analysis of asthma exacerbations. J Allergy Clin Immunol 2001; 107: 783-789.

41 Walter MJ, Castro M, Kunselman SJ, et al. Predicting worsening asthma control following the common cold. Eur Respir J 2008; 32: 1548-1554.

42 Wark PA, Grissell T, Davies B, et al. Diversity in the bronchial epithelial cell response to infection with different rhinovirus strains. Respirology 2009; 14: 180-186.

43 Calvo C, Garcia ML, Pozo F, et al. Role of rhinovirus C in apparently life-threatening events in infants, Spain. Emerg Infect Dis 2009; 15: 1506-1508.

44 Xiang Z, Gonzalez R, Xie Z, et al. Human rhinovirus group C infection in children with lower respiratory tract infection. Emerg Infect Dis 2008; 14: 1665-1667.

45 Wark PA, Tooze M, Powell $\mathrm{H}$, et al. Viral and bacterial infection in acute asthma and chronic obstructive pulmonary disease increases the risk of readmission. Respirology 2013; 18: 996-1002.

46 Reddel HK, Jenkins C, Quirce S, et al. Effect of different asthma treatments on risk of cold-related exacerbations. Eur Respir J 2011; 38: 584-593.

47 Edwards MR, Haas J, Panettieri RA Jr, et al. Corticosteroids and $\beta_{2}$ agonists differentially regulate rhinovirusinduced interleukin-6 via distinct cis-acting elements. J Biol Chem 2007; 282: 15366-15375.

48 Van Ly D, King NJ, Moir LM, et al. Effects of $\beta_{2}$ agonists, corticosteroids, and novel therapies on rhinovirusinduced cytokine release and rhinovirus replication in primary airway fibroblasts. J Allergy 2011; 2011: 457169.

49 Tacon CE, Newton R, Proud D, et al. Rhinovirus-induced MMP-9 expression is dependent on Fra-1, which is modulated by formoterol and dexamethasone. J Immunol 2012; 188: 4621-4630.

50 Skevaki CL, Christodoulou I, Spyridaki IS, et al. Budesonide and formoterol inhibit inflammatory mediator production by bronchial epithelial cells infected with rhinovirus. Clin Exp Allergy 2009; 39: 1700-1710

51 Bochkov Y, Busse W, Brockman-Schneider R, et al. Budesonide and formoterol effects on rhinovirus replication and epithelial cell cytokine responses. Respir Res 2013; 14: 98.

52 Horne R. Compliance, adherence, and concordance: implications for asthma treatment. Chest 2006; 130: Suppl., 65S-72S.

53 Papi A, Contoli M, Adcock I, et al. Rhinovirus infection causes steroid resistance in airway epithelium through nuclear factor $\kappa \mathrm{B}$ and c-Jun N-terminal kinase activation. J Allergy Clin Immunol 2013; 132: 1075-1085.

54 Quon BS, Fitzgerald JM, Lemiere C, et al. Increased versus stable doses of inhaled corticosteroids for exacerbations of chronic asthma in adults and children. Cochrane Database Syst Rev 2010; 12: CD007524.

55 Oommen A, Lambert PC, Grigg J. Efficacy of a short course of parent-initiated oral prednisolone for viral wheeze in children aged 1-5 years: randomised controlled trial. Lancet 2003; 362: 1433-1438.

56 Panickar J, Lakhanpaul M, Lambert PC, et al. Oral prednisolone for preschool children with acute virus-induced wheezing. N Engl J Med 2009; 360: 329-338.

57 Ducharme FM, Lemire C, Noya FJ, et al. Preemptive use of high-dose fluticasone for virus-induced wheezing in young children. N Engl J Med 2009; 360: 339-353.

58 Rowe BH, Spooner C, Ducharme FM, et al. Early emergency department treatment of acute asthma with systemic corticosteroids. Cochrane Database Syst Rev 2001; 1: CD002178.

59 Vuillermin PJ, Robertson CF, Carlin JB, et al. Parent initiated prednisolone for acute asthma in children of school age: randomised controlled crossover trial. BMJ 2010; 340: c843.

60 Chapman KR, Barnes NC, Greening AP, et al. Single maintenance and reliever therapy (SMART) of asthma: a critical appraisal. Thorax 2010; 65: 747-752.

61 Grünberg K, Sharon RF, Sont JK, et al. Rhinovirus-induced airway inflammation in asthma. Am J Respir Crit Care Med 2001; 164: 1816-1822.

62 Grunberg K, Sharon RF, Hiltermann TJ, et al. Experimental rhinovirus 16 infection increases intercellular adhesion molecule-1 expression in bronchial epithelium of asthmatics regardless of inhaled steroid treatment. Clin Exp Allergy 2000; 30: 1015-1023.

63 Gustafson L, Proud D, Hendley J, et al. Oral prednisone therapy in experimental rhinovirus infections. J Allergy Clin Immunol 1996; 97: 1009-1014.

64 Farr BM, Gwaltney JM, Hendley JO, et al. Randomized controlled trial of glucocorticoid prophylaxis against experimental rhinovirus infection. J infect Dis 1990; 162: 1173-1177.

65 Harrison TW, Oborne J, Newton S, et al. Doubling the dose of inhaled corticosteroid to prevent asthma exacerbations: randomised controlled trial. Lancet 2004; 363: 271-275.

66 FitzGerald JM, Becker A, Sears MR, et al. Doubling the dose of budesonide versus maintenance treatment in asthma exacerbations. Thorax 2004; 59: 550-556.

67 National Asthma Council Australia. Asthma Management Handbook 2006. Melbourne, National Asthma Council Australia Ltd, 2006.

68 Oborne J, Mortimer K, Hubbard RB, et al. Quadrupling the dose of inhaled corticosteroid to prevent asthma exacerbations: a randomized, double-blind, placebo-controlled, parallel-group clinical trial. Am J Respir Crit Care Med 2009; 180: 598-602. 
69 Furukawa E, Ohrui T, Yamaya M, et al. Human airway submucosal glands augment eosinophil chemotaxis during rhinovirus infection. Clin Exp Allergy 2004; 34: 704-711.

70 Serisier DJ, Coates AD, Bowler SD. Effect of albuterol on maximal exercise capacity in cystic fibrosis. Chest 2007; 131: 1181-1187.

71 Dodd JD, Barry SC, Daly LE, et al. Inhaled beta-agonists improve lung function but not maximal exercise capacity in cystic fibrosis. J Cyst Fibros 2005; 4: 101-105.

72 Calverley PM, Anderson JA, Celli B, et al. Salmeterol and fluticasone propionate and survival in chronic obstructive pulmonary disease. N Engl J Med 2007; 356: 775-789.

73 Haney S, Hancox RJ. Tolerance to bronchodilation during treatment with long-acting beta-agonists, a randomised controlled trial. Respir Res 2005; 6: 107.

74 Nino G, Hu A, Grunstein JS, et al. Mechanism regulating proasthmatic effects of prolonged homologous B2-adrenergic receptor desensitization in airway smooth muscle. Am J Physiol Lung Cell Mol Physiol 2009; 297: L746-L757.

75 Khor YH, Teoh AKY, Lam SM, et al. Increased vascular permeability precedes cellular inflammation as asthma control deteriorates. Clin Exp Allergy 2009; 39: 1659-1667.

76 Peebles Jr RS, Wagner EM, Liu MC, et al. Allergen-induced changes in airway responsiveness are not related to indices of airway edema. J Allergy Clin Immunol 2001; 107: 805-811.

77 Brown RH, Zerhouni EA, Mitzner W. Visualization of airway obstruction in vivo during pulmonary vascular engorgement and edema. J Appl Physiol (1985) 1995; 78: 1070-1078.

78 Trian T, Ge Q, Moir LM, et al. Rhinovirus-induced exacerbations of asthma - how is the $\beta 2$-adrenoceptor implicated? Am J Respir Cell Mol Biol 2010; 43: 227-233.

79 Wos M, Sanak M, Soja J, et al. The presence of rhinovirus in lower airways of patients with bronchial asthma. Am J Respir Crit Care Med 2008; 177: 1082-1089.

80 Van Ly D, Faiz A, Jenkins C, et al. Characterising the mechanism of airway smooth muscle $\beta_{2}$ adrenoceptor desensitization by rhinovirus infected bronchial epithelial cells. PLoS One 2013; 8: e56058.

81 Korant BD, Lonberg-Holm K, Noble J, et al. Naturally occurring and artificially produced components of three rhinoviruses. Virology 1972; 48: 71-86.

82 Korant BD, Lonberg-Holm K, Yin FH, et al. Fractionation of biologically active and inactive populations of human rhinovirus type 2. Virology 1975; 63: 384-394.

83 Moore PE, Cunningham G, Calder MM, et al. Respiratory syncytial virus infection reduces $\beta 2$-adrenergic responses in human airway smooth muscle. Am J Respir Cell Mol Biol 2006; 35: 559-564.

84 Seymour ML, Gilby N, Bardin PG, et al. Rhinovirus infection increases 5-lipoxygenase and cyclooxygenase-2 in bronchial biopsy specimens from nonatopic subjects. J Infect Dis 2002; 185: 540-544.

85 Gentile DA, Fireman P, Skoner DP. Elevations of local leukotriene C4 levels during viral upper respiratory tract infections. Ann Allergy Asthma Immunol 2003; 91: 270-274.

86 Bacharier LB, Phillips BR, Zeiger RS, et al. Episodic use of an inhaled corticosteroid or leukotriene receptor antagonist in preschool children with moderate-to-severe intermittent wheezing. J Allergy Clin Immunol 2008; 122: $1127-1135$.

87 Johnston NW, Mandhane PJ, Dai J, et al. Attenuation of the September epidemic of asthma exacerbations in children: a randomized, controlled trial of montelukast added to usual therapy. Pediatrics 2007; 120: e702-e712.

88 Kloepfer KM, DeMore JP, Vrtis RF, et al. Effects of montelukast on patients with asthma after experimental inoculation with human rhinovirus 16. Ann Allergy Asthma Immunol 2011; 106: 252-257.

89 Proesmans M, Sauer K, Govaere E, et al. Montelukast does not prevent reactive airway disease in young children hospitalized for RSV bronchiolitis. Acta Paediatr 2009; 98: 1830-1834.

90 Bisgaard H, Flores-Nunez A, Goh A, et al. Study of montelukast for the treatment of respiratory symptoms of postrespiratory syncytial virus bronchiolitis in children. Am J Respir Crit Care Med 2008; 178: 854-860.

91 Kozer E, Lotem Z, Elgarushe M, et al. RCT of montelukast as prophylaxis for upper respiratory tract infections in children. Pediatrics 2012; 129: E285-E290.

92 Fleming HE, Little FF, Schnurr D, et al. Rhinovirus-16 colds in healthy and in asthmatic subjects: similar changes in upper and lower airways. Am J Respir Crit Care Med 1999; 160: 100-108.

93 de Kluijver J, Evertse CE, Sont JK, et al. Are rhinovirus-induced airway responses in asthma aggravated by chronic allergen exposure? Am J Respir Crit Care Med 2003; 168: 1174-1180.

94 Bardin PG, Fraenkel DJ, Sanderson G, et al. Peak expiratory flow changes during experimental rhinovirus infection. Eur Respir J 2000; 16: 980-985.

95 Grunberg K, Smits HH, Timmers MC, et al. Experimental rhinovirus 16 infection. Effects on cell differentials and soluble markers in sputum in asthmatic subjects. Am J Respir Crit Care Med 1997; 156: 609-616.

96 Seymour ML, Gilby N, Bardin PG, et al. Rhinovirus infection increases 5-lipoxygenase and cyclooxygenase-2 in bronchial biopsy specimens from nonatopic subjects. J Infect Dis 2002; 185: 540-544.

97 Bartlett NW, Walton RP, Edwards MR, et al. Mouse models of rhinovirus-induced disease and exacerbation of allergic airway inflammation. Nat Med 2008; 14: 199-204.

98 Nagarkar DR, Bowman ER, Schneider D, et al. Rhinovirus infection of allergen-sensitized and -challenged mice induces eotaxin release from functionally polarized macrophages. J Immunol 2010; 185: 2525-2535.

99 Phan JA, Kicic A, Berry LJ, et al. Rhinovirus exacerbates house-dust-mite induced lung disease in adult mice. PLoS One 2014; 9: e92163.

100 Birrell MA, Van Oosterhout AJM, Belvisi MG. Do the current house dust mite-driven models really mimic allergic asthma? Eur Respir J 2010; 36: 1220-1221.

101 Phipps S, Lam CE, Mahalingam S, et al. Eosinophils contribute to innate antiviral immunity and promote clearance of respiratory syncytial virus. Blood 2007; 110: 1578-1586.

102 Adamko DJ, Yost BL, Gleich GJ, et al. Ovalbumin sensitization changes the inflammatory response to subsequent parainfluenza infection: eosinophils mediate airway hyperresponsiveness, M2 muscarinic receptor dysfunction, and antiviral effects. J Exp Med 1999; 190: 1465-1478.

103 Kupczyk M, ten Brinke A, Sterk PJ, et al. Frequent exacerbators - a distinct phenotype of severe asthma. Clin Exp Allergy 2014; 44: 212-221. 
104 Ortega H, Chupp G, Bardin P, et al. The role of mepolizumab in atopic and nonatopic severe asthma with persistent eosinophilia. Eur Respir J 2014; 44: 239-241.

105 Malerba M, Ragnoli B, Radaeli A, et al. Usefulness of exhaled nitric oxide and sputum eosinophils in the long-term control of eosinophilic asthma. Chest 2008; 134: 733-739.

106 Jarjour NN, Gern JE, Kelly EA, et al. The effect of an experimental rhinovirus 16 infection on bronchial lavage neutrophils. J Allergy Clin Immunol 2000; 105: 1169-1177.

107 Message SD, Laza-Stanca V, Mallia P, et al. Rhinovirus-induced lower respiratory illness is increased in asthma and related to virus load and Th1/2 cytokine and IL-10 production. Proc Natl Acad Sci USA 2008; 105: 13562-13567.

108 Grunberg K, Timmers MC, Smits HH, et al. Effect of experimental rhinovirus 16 colds on airway hyperresponsiveness to histamine and interleukin-8 in nasal lavage in asthmatic subjects in vivo. Clin Exp Allergy 1997; 27: 36-45.

109 Woodruff PG, Khashayar R, Lazarus SC, et al. Relationship between airway inflammation, hyperresponsiveness, and obstruction in asthma. J Allergy Clin Immunol 2001; 108: 753-758.

110 Green RH, Brightling CE, Woltmann G, et al. Analysis of induced sputum in adults with asthma: identification of subgroup with isolated sputum neutrophilia and poor response to inhaled corticosteroids. Thorax 2002; 57: 875-879.

111 Tenor H, Hatzelmann A, Beume R, et al. Pharmacology, clinical efficacy, and tolerability of phosphodiesterase-4 inhibitors: impact of human pharmacokinetics. Handb Exp Pharmacol 2011; 204: 85-119.

112 Wedzicha JA, Rabe KF, Martinez FJ, et al. Efficacy of roflumilast in the chronic obstructive pulmonary disease frequent exacerbator phenotype. Chest 2013; 143: 1302-1311.

113 Hatzelmann A, Morcillo EJ, Lungarella G, et al. The preclinical pharmacology of roflumilast - a selective, oral phosphodiesterase 4 inhibitor in development for chronic obstructive pulmonary disease. Pulm Pharmacol Ther 2010; 23: 235-256.

114 Kuss $\mathrm{H}$, Hoefgen N, Johanssen S, et al. In vivo efficacy in airway disease models of N-(3,5-dichloropyrid-4-yl)-[1(4-fluorobenzyl)-5-hydroxy-indole-3-yl]-glyoxylic acid amide (AWD 12-281), a selective phosphodiesterase 4 inhibitor for inhaled administration. J Pharmacol Exp Ther 2003; 307: 373-385.

115 Trian T, Burgess JK, Niimi K, et al. $\beta_{2}$-Agonist induced cAMP is decreased in asthmatic airway smooth muscle due to increased PDE4D. PLoS One 2011; 6: e20000.

116 Planquois JM, Ruffin Morin Y, Lagente V, et al. Salbutamol potentiates the relaxant effects of selective phosphodiesterase inhibitors on guinea pig isolated trachea. Fundam Clin Pharm 1996; 10: 356-367.

117 Nair P, Gaga M, Zervas E, et al. Safety and efficacy of a CXCR2 antagonist in patients with severe asthma and sputum neutrophils: a randomized, placebo-controlled clinical trial. Clin Exp Allergy 2012; 42: 1097-1103.

118 Kuo C, Lim S, King NJC, et al. Rhinovirus infection induces expression of airway remodelling factors in vitro and in vivo. Respirology 2011; 16: 367-377.

119 Nagarkar DR, Wang Q, Shim J, et al. CXCR2 is required for neutrophilic airway inflammation and hyperresponsiveness in a mouse model of human rhinovirus infection. J Immunol 2009; 183: 6698-6707.

120 de Jongste JC, Carraro S, Hop WC. Daily telemonitoring of exhaled nitric oxide and symptoms in the treatment of childhood asthma. Am J Respir Crit Care Med 2009; 179: 93-97.

121 Kharitonov SA, Yates D, Barnes PJ. Increased nitric oxide in exhaled air of normal human subjects with upper respiratory tract infections. Eur Respir J 1995; 8: 295-297.

122 Sanders SP, Proud D, Permutt S, et al. Role of nasal nitric oxide in the resolution of experimental rhinovirus infection. J Allergy Clin Immunol 2004; 113: 697-702.

123 Rimmelzwaan GF, Baars MM, de LP, et al. Inhibition of influenza virus replication by nitric oxide. J Virol 1999; 73: 8880-8883.

124 Ali-Ahmad D, Bonville CA, Rosenberg HF, et al. Replication of respiratory syncytial virus is inhibited in target cells generating nitric oxide in situ. Front Biosci 2003; 8: a48-a53.

125 de Gouw HW, Grunberg K, Schot R, et al. Relationship between exhaled nitric oxide and airway hyperresponsiveness following experimental rhinovirus infection in asthmatic subjects. Eur Respir J 1998; 11: 126-132.

126 Rossmann MG, Arnold E, Erickson JW, et al. Structure of a human common cold virus and functional relationship to other picornaviruses. Nature 1985; 317: 145-153.

127 Saba TG, Chung Y, Hong JY, et al. Rhinovirus-induced macrophage cytokine expression does not require endocytosis or replication. Am J Respir Cell Mol Biol 2013; 50: 974-984.

128 Gern JE, Joseph B, Galagan DM, et al. Rhinovirus inhibits antigen-specific T cell proliferation through an intercellular adhesion molecule-1-dependent mechanism. J Infect Dis 1996; 174: 1143-1150.

129 Oliver BG, Johnston SL, Baraket M, et al. Increased proinflammatory responses from asthmatic human airway smooth muscle cells in response to rhinovirus infection. Respir Res 2006; 7: 71.

130 Newcomb DC, Sajjan US, Nagarkar DR, et al. Cooperative effects of rhinovirus and TNF- $\alpha$ on airway epithelial cell chemokine expression. Am J Physiol Lung Cell Mol Physiol 2007; 293: L1021-L1028.

131 Gern JE, Dick EC, Lee WM, et al. Rhinovirus enters but does not replicate inside monocytes and airway macrophages. J Immunol 1996; 156: 621-627.

132 Duits LA, Nibbering PH, van Strijen E, et al. Rhinovirus increases human $\beta$-defensin-2 and -3 mRNA expression in cultured bronchial epithelial cells. FEMS Immunol Med Microbiol 2003; 38: 59-64.

133 Ilarraza R, Wu Y, Skappak CD, et al. Rhinovirus has the unique ability to directly activate human $\mathrm{T}$ cells in vitro. J Allergy Clin Immunol 2013; 131: 395-404.

134 Papadopoulos NG, Stanciu LA, Papi A, et al. A defective type 1 response to rhinovirus in atopic asthma. Thorax 2002; 57: 328-332.

135 Wark PA, Johnston SL, Bucchieri F, et al. Asthmatic bronchial epithelial cells have a deficient innate immune response to infection with rhinovirus. J Exp Med 2005; 201: 937-947.

136 Slater L, Bartlett NW, Haas JJ, et al. Co-ordinated role of TLR3, RIG-I and MDA5 in the innate response to rhinovirus in bronchial epithelium. PLoS Pathogens 2010; 6: e1001178.

137 Triantafilou K, Vakakis E, Richer EAJ, et al. Human rhinovirus recognition in non-immune cells is mediated by Tolllike receptors and MDA-5, which trigger a synergetic pro-inflammatory immune response. Virulence 2011; 2: 22-29.

138 Contoli M, Message SD, Laza-Stanca V, et al. Role of deficient type III interferon-[lambda] production in asthma exacerbations. Nat Med 2006; 12: 1023-1026. 
139 Lopez-Souza N, Favoreto S, Wong H, et al. In vitro susceptibility to rhinovirus infection is greater for bronchial than for nasal airway epithelial cells in human subjects. J Allergy Clin Immunol 2009; 123: 1384-1390.

140 Bochkov Y, Hanson K, Keles S, et al. Rhinovirus-induced modulation of gene expression in bronchial epithelial cells from subjects with asthma. Mucosal Immunol 2010; 3: 69-80.

141 DeMore J, Weisshaar E, Vrtis R, et al. Similar colds in subjects with allergic asthma and nonatopic subjects after inoculation with rhinovirus-16. J Allergy Clin Immunol 2009; 124: 245-252.

142 Spann KM, Baturcam E, Schagen J, et al. Viral and host factors determine innate immune responses in airway epithelial cells from children with wheeze and atopy. Thorax 2014; 69: 918-925.

143 Sykes A, Macintyre J, Edwards MR, et al. Rhinovirus-induced interferon production is not deficient in well controlled asthma. Thorax 2014; 69: 240-246.

144 Pollard AJ, Isaacs A, Hermione Lyall EG, et al. Potentially lethal bacterial infection associated with varicella zoster virus. BMJ 1996; 313: 283-285.

145 Hussell T, Williams A. Ménage a trois of bacterial and viral pulmonary pathogens delivers coup de grace to the lung. Clin Exp Immunol 2004; 137: 8-11.

146 Hament JM, Kimpen JL, Fleer A, et al. Respiratory viral infection predisposing for bacterial disease: a concise review. FEMS Immunol Med Microbiol 1999; 26: 189-195.

147 Peltola VT, McCullers JA. Respiratory viruses predisposing to bacterial infections: role of neuraminidase. Pediatr Infect Dis J 2004; 23: Suppl., S87-S97.

148 Okamoto S, Kawabata S, Terao Y, et al. The Streptococcus pyogenes capsule is required for adhesion of bacteria to virus-infected alveolar epithelial cells and lethal bacterial-viral superinfection. Infect Immun 2004; 72: 6068-6075.

149 Ishizuka S, Yamaya M, Suzuki T, et al. Effects of rhinovirus infection on the adherence of Streptococcus pneumoniae to cultured human airway epithelial cells. J Infect Dis 2003; 188: 1928-1939.

150 Oliver BG, Lim S, Wark P, et al. Rhinovirus exposure impairs immune responses to bacterial products in human alveolar macrophages. Thorax 2008; 63: 519-525.

151 Talbot TR, Hartert TV, Mitchel E, et al. Asthma as a risk factor for invasive pneumococcal disease. N Engl J Med 2005; 352: 2082-2090.

152 Wark PA, Johnston SL, Simpson JL, et al. Chlamydia pneumoniae immunoglobulin A reactivation and airway inflammation in acute asthma. Eur Respir J 2002; 20: 834-840.

153 Cunningham AF, Johnston SL, Julious SA, et al. Chronic Chlamydia pneumoniae infection and asthma exacerbations in children. Eur Respir J 1998; 11: 345-349.

154 Piacentini GL, Peroni DG, Bodini A, et al. Azithromycin reduces bronchial hyperresponsiveness and neutrophilic airway inflammation in asthmatic children: a preliminary report. Allergy Asthma Proc 2007; 28: 194-198.

155 Simpson JL, Powell H, Boyle MJ, et al. Clarithromycin targets neutrophilic airway inflammation in refractory asthma. Am J Respir Crit Care Med 2008; 177: 148-155.

156 Johnston SL, Blasi F, Black PN, et al. The effect of telithromycin in acute exacerbations of asthma. N Engl J Med 2006; 354: 1589-1600.

157 Girgis ST, Marks GB, Downs SH, et al. Thunderstorm-associated asthma in an inland town in south-eastern Australia. Who is at risk? Eur Respir J 2000; 16: 3-8.

158 Wark PA, Simpson J, Hensley MJ, et al. Airway inflammation in thunderstorm asthma. Clin Exp Allergy 2002; 32: 1750-1756.

159 Green RM, Custovic A, Sanderson G, et al. Synergism between allergens and viruses and risk of hospital admission with asthma: case-control study. BMJ 2002; 324: 763.

160 Rakes GP, Arruda E, Ingram JM, et al. Rhinovirus and respiratory syncytial virus in wheezing children requiring emergency care. IgE and eosinophil analyses. Am J Respir Crit Care Med 1999; 159: 785-790.

161 Jartti T, Kuusipalo H, Vuorinen T, et al. Allergic sensitization is associated with rhinovirus-, but not other virus-, induced wheezing in children. Pediatr Allergy Immunol 2010; 21: 1008-1014.

162 Soto-Quiros M, Avila L, Platts-Mills TAE, et al. High titers of IgE antibody to dust mite allergen and risk for wheezing among asthmatic children infected with rhinovirus. J Allergy Clin Immunol 2012; 129: 1499-1505.

163 Rees PJ. Omalizumab reduces exacerbation and steroid use in chronic asthma. Evid Based Med 2007; 12: 11.

164 Busse WW, Morgan WJ, Gergen PJ, et al. Randomized trial of omalizumab (anti-IgE) for asthma in inner-city children. N Engl J Med 2011; 364: 1005-1015.

165 Calhoun WJ, Dick EC, Schwartz LB, et al. A common cold virus, rhinovirus 16, potentiates airway inflammation after segmental antigen bronchoprovocation in allergic subjects. J Clin Invest 1994; 94: 2200-2208.

166 Calhoun WJ, Swenson CA, Dick EC, et al. Experimental rhinovirus 16 infection potentiates histamine release after antigen bronchoprovocation in allergic subjects. Am Rev Respir Dis 1991; 144: 1267-1273.

167 Lemanske RF Jr, Dick EC, Swenson CA, et al. Rhinovirus upper respiratory infection increases airway hyperreactivity and late asthmatic reactions. J Clin Invest 1989; 83: 1-10.

168 Avila PC, Abisheganaden JA, Wong H, et al. Effects of allergic inflammation of the nasal mucosa on the severity of rhinovirus 16 cold. J Allergy Clin Immunol 2000; 105: 923-932.

169 Wark PAB, Bucchieri F, Johnston SL, et al. IFN- $\gamma$-induced protein 10 is a novel biomarker of rhinovirus-induced asthma exacerbations. J Allergy Clin Immunol 2007; 120: 586-593.

170 Karron R, Wright P, Belshe R, et al. Identification of a recombinant live attenuated respiratory syncytial virus vaccine candidate that is highly attenuated in infants. J Infect Dis 2005; 191: 1093-1104.

171 Karron RA, Talaat K, Luke C, et al. Evaluation of two live attenuated cold-adapted H5N1 influenza virus vaccines in healthy adults. Vaccine 2009; 27: 4953-4960.

172 Glanville N, McLean GR, Guy B, et al. Cross-serotype immunity induced by immunization with a conserved rhinovirus capsid protein. PLoS Pathogens 2013; 9: e1003669.

173 Pevear DC, Hayden FG, Demenczuk TM, et al. Relationship of pleconaril susceptibility and clinical outcomes in treatment of common colds caused by rhinoviruses. Antimicrob Agents Chemother 2005; 49: 4492-4499.

174 Stone JK, Rijnbrand R, Stein DA, et al. Morpholino oligomer targeting highly conserved internal ribosome entry site sequence is able to inhibit multiple species of picornavirus. Antimicrob Agents Chemother 2008; 52: 1970-1981.

175 Djukanović R, Harrison T, Johnston SL, et al. The effect of inhaled interferon- $\beta$ on worsening of asthma symptoms caused by viral infections: a randomised trial. Am J Respir Crit Care Med 2014; 190: 145-154. 